\title{
Predaceous Ant Fauna in New Sugarcane Fields in the State of São Paulo, Brazil
}

\author{
Marcelo Nogueira Rossi ${ }^{1 *}$ and Harold Gordon Fowler ${ }^{2}$ \\ ${ }^{1}$ Departamento de Parasitologia - IB; Universidade Estadual Paulista; 18618-000; rossilife@fca.unesp.br; \\ Botucatu - SP - Brazil. ${ }^{2}$ Departamento de Ecologia - IB; Universidade Estadual Paulista; Rio Claro - São Paulo - \\ Brazil
}

\begin{abstract}
Predaceous ant fauna present in natural sugarcane field plantations in the state of São Paulo, Brazil, was evaluated by using sardine baits sampling technique. Three-month-old sugarcane plants were used for ant fauna estimation in two sugarcane mills, São João and Barra Mill. Twelve $30 \mathrm{~m} X 30 \mathrm{~m}\left(900 \mathrm{~m}^{2}\right)$ plots were previously delimited in each sugarcane mill for ant sampling. Ants were sampled in each plot by placing nine sardine baits in $12 \mathrm{~mm} X 75 \mathrm{~mm}$ plastic tubes. In the São João Mill, the predominant ant species observed was Solenopsis saevissima, followed by Dorymyrmex sp. 1, Pheidole sp. 2, and Crematogaster sp. 1. Considering only ant genus, Solenopsis, Pheidole, Dorymyrmex, and Crematogaster, were predominant. In the Barra Mill, the predominant ant genus sampled was Solenopsis, followed by Pheidole, Crematogaster, and Dorymyrmex. As generalist predatory ants could be one of the reasons for the naturally low levels of D. saccharalis infestation on sugarcane in the state of São Paulo, this study could be helpful for the researchers to gain knowledge about the fauna of predaceous ants which acted as predators of eggs and early larval stages of D. saccharalis in Brazil.
\end{abstract}

Key words: Ants, predation, Diatraea saccharalis, sugarcane, Solenopsis, Pheidole

\section{INTRODUCTION}

The sugarcane borer, Diatraea saccharalis Fabricius (Lepidoptera: Crambidae) is the main sugarcane pest in Brazil (Gallo et al., 1988). It causes direct injury through gallery construction, leading to weight loss and germination failure, and indirect losses by facilitating fungus infections that lead to sucrose inversion and a consequent loss of sugar during refinement (Gallo et al., 1988). In the state of São Paulo, Brazil, the only active population control of $D$. saccharalis is by inundative releases of the exotic parasitoid, Cotesia flavipes Cameron (Hymenoptera: Braconidae) and current infestation rates are approximately 2\% (Botelho, 1992; Botelho et al., 1999). However, the production of $C$. flavipes in sugar mills entails costs and few studies have evaluated the effects of native predators on sugarcane borer populations.

Generalist predators can be effective regulatory agents of pest populations because they can adjust predation between a number of prey population, whether these are primary or secondary pests (Luff, 1983). One of the most common generalist predators in tropical forests are ants (Hymenoptera: Formicidae). For certain crops, a few species may dominate fields, despite high species richness (Adams et al., 1981; Risch and Carroll, 1982; Botelho et al., 1986).

\footnotetext{
* Author for correspondence
} 
Ants have been mentioned as being important predators of the sugarcane borer $D$. saccharalis. Larval and egg cane borer stages are attacked by fire ants, Solenopsis invicta Buren (Hymenoptera: Formicidae). The constant use of heptachlor and dodecachlor (Reagan et al., 1972) for fire ant abatement programs resulted in drastic population reductions of fire ants S. invicta and three-fold increase of sugarcane borer populations in the United States (Charpentier et al., 1967; Negm and Hesley, 1969). Vogt et al. (2001), studying prey items collected by foraging $S$. invicta in an Oklahoma peanut field, observed that the largest percentage of foraged items were lepidopteran larvae, and these ants collected seven times more pest arthropods than beneficial arthropods. Fire ants have also been shown to be key predators for row crop pests in the Neotropics (Risch and Carroll, 1982) and a variety of pests in Florida and Louisiana (Cherry and Nuessly, 1992; $\mathrm{Hu}$ and Frank, 19966, ; Fuller et al., 1997).

Through artificial infestations of sugarcane fields in the state of São Paulo (Brazil), Rossi and Fowler (2000) observed that fire ants were the most abundant ants. However, a wider description of the predatory ant fauna was absent in such study. Sousa-Silva et al. (1992), studying the fauna of predators of $D$. saccharalis in a sugarcane field in the state of São Paulo, Brazil, by using P-32 radio-isotop (marking sugarcane borer larvae and eggs), found that the main predators of the sugarcane borer were ants. The main ants sampled in this study were Ectatoma quadridens Fabricius, Solenopsis sp. and Gnamptogenys sp. Roger. However, these ant species have not frequently been observed by sugarcane mill field workers, exception to Solenopsis sp. (Harold Gordon Fowler, personal communication), raising doubts whether these ants are really part of the most abundant predaceous ant species in sugarcane fields. As ants are the most important predators of the sugarcane borer in Brazil, the correct information of the predaceous ant fauna present in sugarcane fields is indeed important. In order to elucidate this question, in this study we investigated the fauna of predaceous ants present in sugarcane fields of two sugarcane mills in the state of São Paulo, Brazil.

\section{MATERIALS AND METHODS}

Three-month-old sugarcane fields (variety SP 79-1011) in Aguaí, São Paulo, Brazil (22 01'30’S, $47^{\circ} 08^{\prime} 30^{\prime} \mathrm{W}$ ), were used for estimation of the predaceous ant fauna. Twelve $30 \mathrm{~m} \mathrm{X} 30 \mathrm{~m}$ $\left(900 \mathrm{~m}^{2}\right)$ plots were previously delimited for ant sampling. Ants were sampled in each plot by placing nine sardine baits (canned sardines), contained in $12 \mathrm{~mm} \mathrm{X} 75 \mathrm{~mm}$ plastic tubes, three every five rows of sugarcane, with an $8 \mathrm{~m}$ spacing between baits on the same row. Baits were left for $50 \mathrm{~min}$ and then collected for subsequent species identification. Three days of sampling were performed considering an interval of fifteen days among them. Areas used for samples were located at the São João sugarcane Mill.

Another set of field samples was again taken in newly planted sugarcane (three-month-old) (variety RB 83-5486), but approximately $150 \mathrm{Km}$ south-west of the first area $\left(22^{\circ} 35^{\prime} 30^{\prime} \mathrm{S}\right.$, $\left.48^{\circ} 33^{\prime} 50^{\prime} \mathrm{W}\right)$. As in the first selected sampling area mentioned above, twelve $900 \mathrm{~m}^{2}$ plots were baited in an identical manner to determine the predaceous ant fauna. As above, three days of sampling were performed considering an interval of fifteen days among them. Areas used for samples were located at the Barra sugarcane Mill. As this second set of samples was taken three months later than the first one, only the four most abundant predaceous ant genus were identified since the ant species sampled repeated when compared with those sampled in the São João Mill. The abundance of ant species (or genus, in the second set of samples) sampled in each day was estimated by summing the number of plastic tubes containing a given ant species in all 12 plots. The abundance of ants was then bar plotted to its corresponding ant species, however, these plots were performed only for the total of ants sampled in the three days. A similar plot was also performed considering only the ant genus.

\section{RESULTS}

The abundance of predaceous ant species sampled per day of sampling in the São João Mill is given in Table 1. A total of sixteen predaceous ant species was sampled during the period of study (Fig. 1). For all days sampled, Solenopsis saevissima Forel was the predominant ant, comprising $28 \%$ of occupied 
baits (21 in a total of 75 sardine baits occupied by ants), followed by Dorymyrmex sp. 1 (12\%), Pheidole sp. 2 (8\%) and Crematogaster sp. 1 (8\%) (Fig. 1). Thus, these ant species comprised $56 \%$ of occupied baits and the remaining ant species comprised the other $44 \%$ (Fig. 1). However, for ant genus only, Solenopsis comprised $40 \%$ of occupied baits (30 in a total of 75 sardine baits), Pheidole (23\%), Dorymyrmex (13\%) and Crematogaster (12\%) (Fig. 2), hence, these ant genus comprised
$88 \%$ of occupied baits. Thus, Ectatomma, Camponotus and Brachymyrmex genus comprised only $12 \%$ of the occupied baits.

The abundance of predaceous ant genus sampled per day of sampling in the Barra Mill is given in Table 2. In all the days sampled, Solenopsis was the predominant ant genus, comprising $41 \%$ of occupied baits (44 in a total of 107 sardine baits occupied by ants), followed by Pheidole (33\%), Crematogaster (14\%) and Dorymyrmex (12\%) (Fig. 3).

Table 1 - Abundance of predaceous ant species considering each day sampled in the São João Mill.

\begin{tabular}{|c|c|}
\hline Ant species in the first day of sampling & Number of sardine baits containing ants \\
\hline Solenopsis saevissima & 12 \\
\hline Ectatomma rudium & 3 \\
\hline Solenopsis invicta & 3 \\
\hline Dorymyrmex sp.1 & 2 \\
\hline Solenopsis (complex) tridens & 1 \\
\hline Pheidole sp. 1 & 1 \\
\hline \multicolumn{2}{|l|}{ Ant species in the second day of sampling } \\
\hline Pheidole sp. 2 & 5 \\
\hline Solenopsis saevissima & 3 \\
\hline Pheidole oxyops & 3 \\
\hline Dorymyrmex sp. 1 & 3 \\
\hline Pheidole sp. 3 & 3 \\
\hline Crematogaster sp. 1 & 3 \\
\hline Ectatomma quadridens & 3 \\
\hline Crematogaster sp. 2 & 3 \\
\hline Dorymyrmex sp. 2 & 1 \\
\hline Solenopsis (complex) tridens & 1 \\
\hline Ectatomma rudium & 1 \\
\hline Camponotus abdomanalis & 1 \\
\hline \multicolumn{2}{|l|}{ Ant species in the third day of sampling } \\
\hline Solenopsis saevissima & 6 \\
\hline Dorymyrmex sp. 1 & 4 \\
\hline Solenopsis (complex) tridens & 3 \\
\hline Crematogaster sp. 1 & 3 \\
\hline Pheidole oxyops & 2 \\
\hline Pheidole sp. 4 & 2 \\
\hline Solenopsis invicta & 1 \\
\hline Brachymyrmex sp. 1 & 1 \\
\hline Pheidole sp. 2 & 1 \\
\hline Total of occupied baits & 75 \\
\hline
\end{tabular}




\section{DISCUSSION}

As predaceous ants have been reported as the main biological control agents of $D$. saccharalis eggs and early larval stages in sugarcane fields in Brazil (Campiolo, 1994), our study shows which ant species have probably contributed to such effect. The number of sardine baits containing ants was small when compared to the total of baits disposed in the field (see the total of occupied baits in the tables).

Table 2 - Abundance of predaceous ant genus considering each day of sampling in the Barra Mill.

\begin{tabular}{lc}
\hline Ant genus in the first day & Number of sardine baits containing ants \\
\hline Solenopsis & 18 \\
Pheidole & 15 \\
Crematogaster & 10 \\
Dorymyrmex & 1 \\
\hline Ant genus in the second day & 13 \\
Solenopsis & 12 \\
Pheidole & 4 \\
Crematogaster & 4 \\
Dorymyrmex & \\
Ant genus in the third day & 13 \\
\hline Solenopsis & 8 \\
Pheidole & 8 \\
Dorymyrmex & 1 \\
Crematogaster & 107 \\
\hline Total of occupied baits &
\end{tabular}

It probably occurred because we carried out the experiments over new sugarcane plants (threemonth-old), thus, the arthropod fauna could be recovering their populations from the last sugarcane harvest.

The predaceous ant fauna collected by Souza-Silva et al. (1992) did not fully corroborate to our data. The ants E. quadridens and Gnamptogenys sp. were not the predominant ant fauna observed in our study because E. quadridens was rarely collected in our field plots, and Gnamptogenys sp. was not even sampled (Fig. 1, 2 and 3). However, Solenopsis sp., which was widely collected by these authors, was the predominant ant genus observed here (Fig. 2 and 3). This difference of results was probably related to the difference in the sampling techniques adopted in both the studies. Souza-Silva et al. (1992) used manual sampling and soil traps for predaceous arthropod estimation, (although they did not do any mention about the kind of soil trap that was adopted) and we used sardine baits. Apparently, sampling technique adopted by Souza-Silva et al. (1992) was probably misused, resulting in part, in an unclear estimation of the predominant ants habiting sugarcane fields in the state of São Paulo, Brazil. Another possible reason for the discrepancy in such results was that the experiments carried out by the authors mentioned above were spatially limited, sampling only ants that were occasionally present in those particular sugarcane plots. As generalist predatory ants could be one of the reasons for the naturally low levels of D. saccharalis infestation on sugarcane in the state of São Paulo (Rossi and Fowler, 2000), this study could be helpful for the researchers to gain knowledge about the fauna of predaceous ants which acted as predators of eggs and early larval stages of $D$. saccharalis in Brazil. 


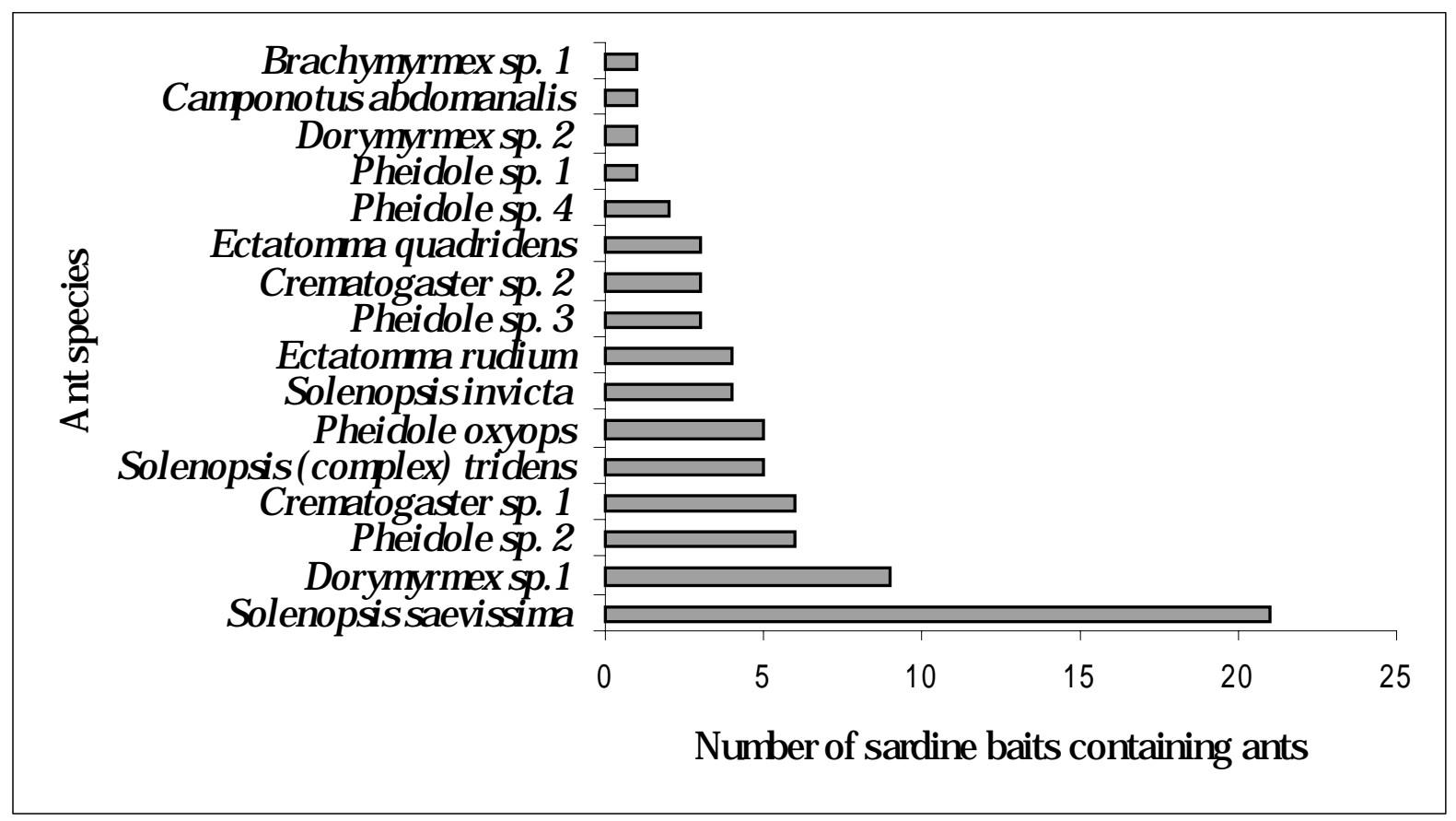

Figure 1 - Abundance of predaceous ant species, considering all days of sampling in the São João Mill.

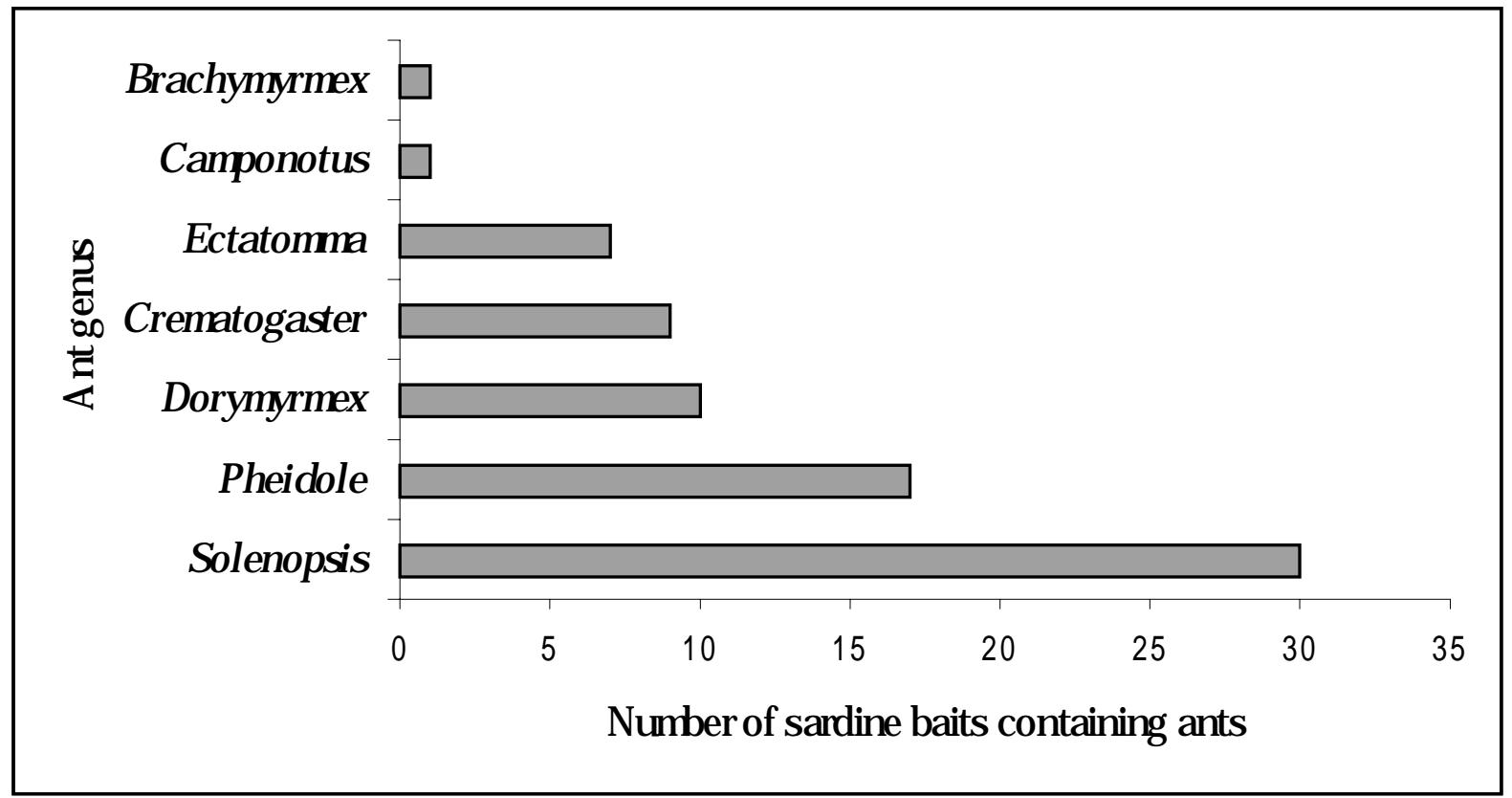

Figure 2 - Abundance of predaceous ant genus, considering all days of sampling in the São João Mill. 


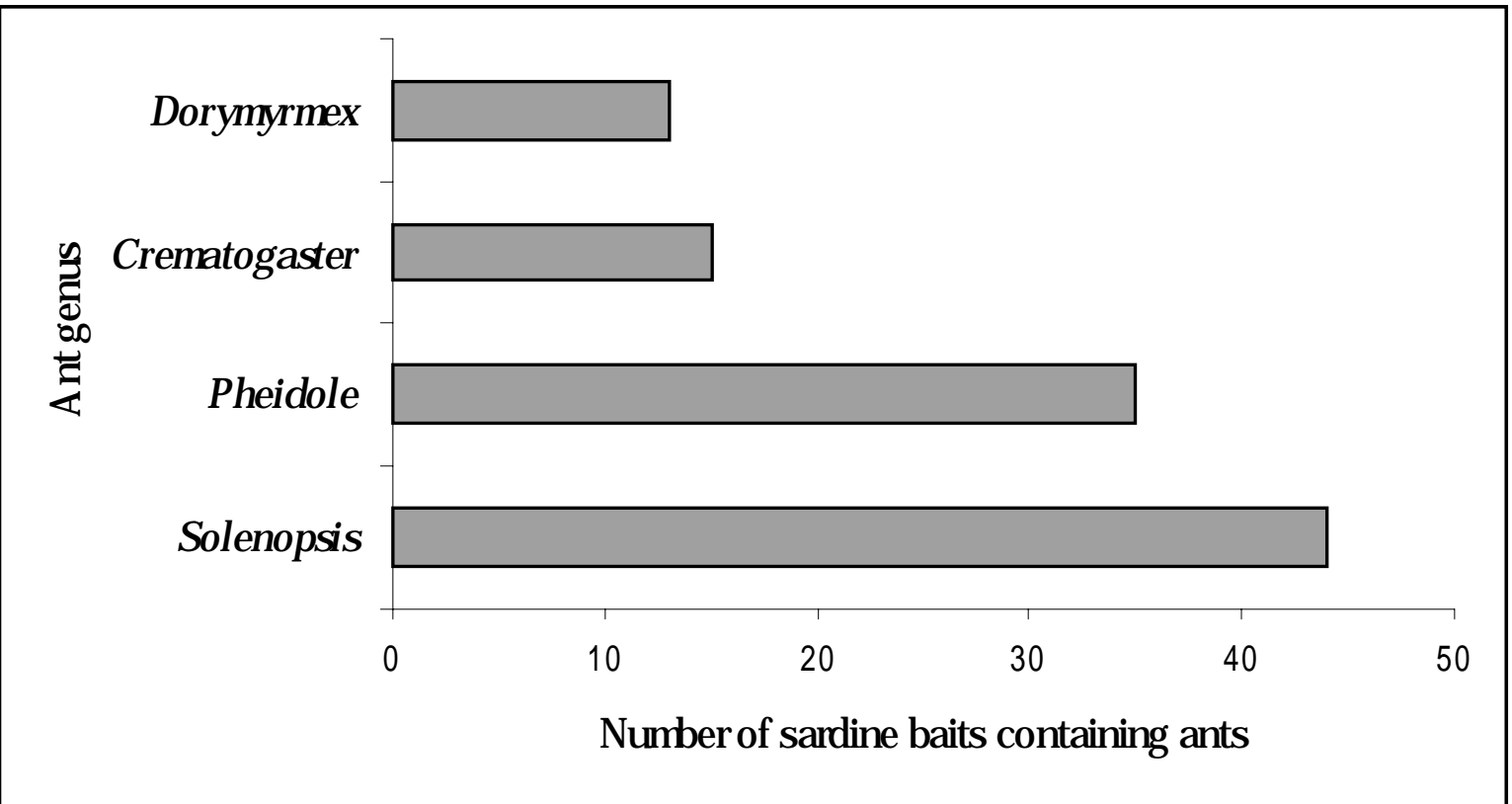

Figure 3 - Abundance of the four main predaceous ant genus, considering all days of sampling in the Barra Mill.

\section{ACKNOWLEDGEMENTS}

We would like to thank the São João and Barra Sugarcane Mills for providing experimental areas and field assistance. Maria Aparecida Piva and Luis Carlos Lacerda Resende of the São João Mill, and Maria Isabel and Cassio Manin Paggiaro of Barra Mill were more than helpful, and provided additional support and shared their knowledge with us. Studies were supported by a research scholarship to M. N. R. by the Brazilian National Science Council (CNPq). We thank Dr. Wesley Augusto Conde Godoy for his helpful comments, improving the final version of this manuscript.

\section{RESUMO}

A fauna de formigas predadoras presentes em lavouras de cana-de-açúcar localizadas no Estado de São Paulo, Brasil, foi avaliada utilizando-se iscas de sardinha. Plantas de três meses de idade foram utilizadas para a estimativa da fauna de formigas predadoras em duas usinas de cana-deaçúcar, usina São João e usina da Barra. Doze áreas $\left[30 \mathrm{~m}\right.$ X $30 \mathrm{~m}\left(900 \mathrm{~m}^{2}\right)$ cada] foram previamente delimitadas em cada usina para a coleta das formigas. As formigas foram amostradas colocando-se nove iscas no solo por área, sendo cada isca composta por um tubo de ensaio plástico $(12 \mathrm{~mm} \mathrm{X} 75 \mathrm{~mm})$, contendo sardinha em seu interior. Na usina São João, a espécie de formiga predominante observada foi Solenopsis saevissima, seguida por Dorymyrmex sp. 1, Pheidole sp. 2, and Crematogaster sp. 1. Considerando apenas o gênero, os mais abundantes foram Solenopsis, Pheidole, Dorymyrmex e Crematogaster. Na usina da Barra, o gênero predominante amostrado foi Solenopsis, seguido por Pheidole, Crematogaster e Dorymyrmex. Como a predação por formigas predadoras generalistas deve ser uma das razões para os baixos níveis populacionais das infestações de Diatraea saccharalis em lavouras de cana-deaçúcar no Estado de São Paulo, este estudo ajudará futuras pesquisas destinadas a se conhecer as formigas predadoras que de fato agem como predadoras de ovos e estágios larvais iniciais de $D$. saccharalis no Brasil.

\section{REFERENCES}

Adams, C. T.; Summers, T. E.; Lofgren, C. S.; Focks, D. A. and Prewitt, J. C. (1981), Interrelationship of ants and the sugarcane borer in Florida sugarcane fields. Environ. Entomol., 10, 415-418. 
Botelho, P. S. M. (1992), Quinze anos de controle biológico da Diatraea saccharalis utilizando parasitóides. Pesq. Agropec. Bras., 27, 255-262.

Botelho, P. S. M.; Macedo, N.; Almeida, L. C.; Castilho, H. J. and Araujo, J. R. (1986), Inovações tecnológicas visando o controle integrado de Diatraea saccharalis. In: Botelho, P. S. M. (Ed.). Avaliação do Controle Biológico da Broca da Cana-de-Açúcar, Diatraea saccharalis. Coopersucar, Sertãozinho (SP). pp. 50-79.

Botelho, P. S. M.; Parra, J. R. P.; Neto, J. F. C. and Oliveira C. P. B. (1999), Associação do Parasitóide de ovos Trichogramma galloi Zucchi (Hymenoptera: Trichogrammatidae) e do parasitóide larval Cotesia flavipes (Cam.) (Hymenoptera: Braconidae) no controle de Diatraea saccharalis, (Fabr.) (Lepidoptera: Crambidae) em cana-de-açúcar. An. Soc. Entomol. Bras. 28, 491-496.

Campiolo, S. (1994), Predação de Diatraea saccharalis (Lepidoptera: Pyralidae) por formigas (Hymenoptera: Formicidae). MSc Thesis, Universidade Estadual Paulista, Rio Claro, Brazil.

Charpentier, L. J.; Mccormick, W. J. and Mathes, R. (1967), Beneficial arthropods inhabiting sugarcane fields and their effect on borer infestation. Sugar Bull., 45, 276-277.

Cherry, R. H. and Nuessly, G. S. (1992), Distribution and abundance of imported fire ants (Hymenoptera, Formicidae) in Florida sugarcane fields. Environ. Entomol., 21, 767-770.

Fuller, B. W.; Reagan, T. E.; Flynn, J. L. and Boetel, M. A. (1997), Predation on fall armyworm (Lepidoptera: Noctuidae) in sweet sorghum. J. Agric. Entomol., 14, 151- 155.

Gallo, D.; Nakano, O.; Silveira-Neto, S.; Carvalho, R. P. L.; Batista, G. C.; Berti-Filho, E.; Parra, J. R. P.; Zucchi, R. A.; Alves, S. B. and Vendramim, J. D. (1988), Manual de Entomologia Agrícola. São Paulo : Agronômica Ceres.

Hu, G. Y. and Frank, J. H. $\left(1996^{\mathrm{a}}\right)$, Effect of the arthropod community on survivorship of immature Haematobia irritans (Diptera: Muscidae) in north central Florida. Florida Entomol., 79, 497-503.

Hu, G. Y. and Frank, J. H. (1996 ${ }^{\mathrm{b}}$ ), Effect of the red imported fire ant (Hymenoptera: Formicidae) on dung-inhabiting arthropods in Florida. Environ. Entomol., 25, 1290-1296.

Luff, M. L. (1983), The potential of predators for pest control. Agric. Ecosystems Environ., 10, 159-181.

Negm, A. A. and Hensley, S. D. (1969), Evaluation of certain biological control agents of the sugarcane borer in Louisiana. J. Econ. Entomol., 62, 1008-1013.

Reagan, T. E.; Coburn, G. and Hensley, S. D. (1972), Effects of mirex on the arthropod fauna of a Louisiana sugarcane field. Environ. Entomol., 1, 588-591.
Risch, S. J. and Carroll, C. R. (1982), Effect of a keystone predaceous ant, Solenopsis geminata, on arthropods in a tropical agroecosystem. Ecology, 63, 1979-1983.

Rossi, M. N. and Fowler, H. G. (2000), Ant predation of larval Diatraea saccharalis Fab. (Lep., Crambidae) in new sugarcane in Brazil. J. Appl. Entomol., 124, 245-247.

Sousa-Silva, C. R.; Sgrillo, R. B.; Oliveira, A. R. and Pacheco, J. M. (1992), Uso do P-32 no estudo de predadores de Diatraea saccharalis (Fabricius, 1794) (Lepidoptera: Pyralidae). An. Soc. Entomol. Bras., 21, 133-138.

Vogt, J. T.; Grantham, R. A.; Smith, W. A. and Arnold, D. C. (2001), Prey of the red imported fire ant (Hymenoptera: Formicidae) in Oklahoma peanuts. Environ. Entomol., 30, 123-128.

Received: April 22, 2003; Revised: August 27, 2003; Accepted: March 12, 2004. 